\title{
DECISION SUPPORT CONCEPT FOR MANAGING THE MAINTENANCE OF CITY PARKING FACILITIES
}

\author{
Nikša Jajac \\ University of Split, Faculty of Civil Engineering, Architecture and Geodesy, Assistant Professor \\ Ivan Marović \\ University of Rijeka, Faculty of Civil Engineering, Senior Assistant \\ Corresponding author: ivan.marovic@uniri.hr \\ Martina Baučić \\ University of Split, Faculty of Civil Engineering, Architecture and Geodesy, M.Sc.
}

\begin{abstract}
In this paper, we study the maintenance of city parking facilities (CPFs), specifically on modeling and support for decision-making related to planning CPF maintenance. Managing the maintenance of CPFs is complicated because it is a multi-disciplinary problem involving many participants, huge quantities of information, limited budgets, and conflicts of goals and criteria. These facts indicate that the decision-making processes in managing the maintenance of CPFs are ill-defined problems. To help maintenance managers cope with this complexity, we propose an approach that combines analytic hierarchy processing (AHP) and PROMETHEE multicriteria methods, and apply this approach to a priority-setting problem. After assessing the conditions of existing CPFs and the planned states of those CPFs, our approach produced a goal tree and criteria, and defined possible actions for the parking facilities. Representatives of stakeholders provided criteria weights by applying the AHP method. Using PROMETHEE II, we ranked the priorities, and the PROMETHEE V method allowed us to define the implementation phases of maintenance, producing the final maintenance plan. We validated our concept in the city of Split.
\end{abstract}

Keywords: maintenance management, decision support, city parking, multicriteria methods

\section{KONCEPT ZA PODRŠKU ODLUČIVANJU U UPRAVLJANJU ODRŽAVANJEM GRADSKIH PARKINGA}

Sažetak: Fokus ovoga rada usmjeren je na fazu održavanja u projektima gradskih parkinga. Uže područje predstavljenog istraživanja je modeliranje podrške odlučivanju vezano uz planiranje održavanja. Upravljanje održavanjem gradskim parkinzima implicira kompleksni proces odlučivanja. Razlozi kompleksnosti su: veliki broj dionika, multidisciplinarnost, velika količina podataka, ograničen budžet, suprotstavljenost ciljeva i kriterija (dakle, tipični problemi upravljanja održavanjem gradske infrastrukture). Ove činjenice ukazuju da odlučivanje u upravljanju održavanjem gradskih parkinga spada u slabo strukturirane probleme. Radi pomaganja managerima održavanja u suočavanju s takvom kompleksnošću, predloženo je angažiranje višekriterijskih metoda AHP i PROMETHEE. Višekriterijski pristup je korišten za prioritetno rangiranje. Analiziranjem postojećeg (procjenjivanjem stanja gradskih parkinga tijekom monitoringa) i planiranog stanja parkinga u gradu, uspostavljeni su stablo ciljeva i kriteriji (ciljevi posljednje hijerarhijske razine u stablu ciljeva). Sukladno tome, definirana su alternativna rješenja/lokacije parkinga. Korištenjem metode AHP, predstavnici dionika odredili su težine kriterija. PROMETHEE II je korištena za prioritetno rangiranje, a temeljem PROMETHEE $V$ definirane su faze implementacije. Rezultat prezentiranog koncepta je plan održavanja. Koncept je validiran na primjeru grada Splita.

Ključne riječi: upravljanje održavanjem, podrška odlučivanju, gradski parking, višekriterijske metode 


\section{INTRODUCTION}

Deciding how to maintain and manage the ever-growing urban road infrastructure-including roads, bridges, tunnels, and parking facilities-is a difficult and socially sensitive activity. City authorities must manage maintenance projects for urban road infrastructure in ways that meet the requirements of all stakeholders while allowing for sustainable development. Maintenance becomes even more complex when it must be planned and implemented on a strict schedule, as is often required. In this case, planning is never-ending and dynamic because maintenance cannot be stopped in an active city. Considering that a well-maintained city can be a more active city, a well-maintained infrastructure offers the city's residents a better quality of life. Thus, maintenance planning should be made as efficient as possible by using appropriate decision tools.

There is much research on supporting decisions related to managing the infrastructure of urban roads. For example, Bielli [1] demonstrated a decision support system (DSS) approach to managing urban traffic, aiming to maximize the efficiency and productivity of the traffic system. Other literature has explored cost-benefit evaluations of potential infrastructure investments and several decision support models [2-4]. For example, Quintero et al. [5] described an improvement to DSS called IDSS (intelligent decision support system), which coordinates the management of urban infrastructures, such as sewage and water. Leclerc et al. [6] provided an IDSS module for managing complaints related to urban infrastructure. Coutinho-Rodrigues et al. [7] provided a spatial decision support system for planning urban infrastructure, integrating a geographic information system (GIS) and the simple additive weighting (SAW) method. In their paper, they noted that their procedure could be used to plan other types of infrastructure, including transport infrastructure.

There are many other studies on urban road infrastructure, including on stationary traffic and its infrastructure, planning, decision making, and maintenance [8-12]. However, this research has focused only on routine and periodic (resealing and rehabilitation) maintenance, emergency and extraordinary activities such as repairs of sudden, accidental damage and road failure (particularly in parking facilities); infrastructure has not been widely studied.

That said, some authors have studied infrastructure. For example, Rouse and Chiu [13] described an optimal way to manage lifecycles in road maintenance in New Zealand, giving much information on maintaining the important characteristics of road infrastructure elements. Many of these characteristics, important for planning maintenance, are the same or very similar to those for parking facilities, especially for on-street parking. They also provide best practices for optimal maintenance. In another study, Huang et al. [14] developed a lifecycle assessment tool for the construction and maintenance of asphalt pavements.

While making maintenance decisions, one must remember how the maintenance will affect the environment and traffic flow. To address these issues, Huang et al. [15] studied how various types of road maintenance generated emissions and disrupted traffic. Later, we will describe the research that most influenced our approach to the decision support concept (DSC), used to support the maintenance management for city parking facilities (CPFs).

Figure 1 shows the structure of our proposed DSC, showing its three decision levels (strategic, tactical, and operative) used for managing urban infrastructure, based on research by Jajac et al. $[3,4,10,16]$. The three management levels are separated by the scope of the decision-making process, where strategic is the broadest and operative the narrowest. This modular concept is based on the basic structure of the DSS: data, dialog, models. The modules interact during decision-making at all management levels, which serve as meeting points of adequate models and data. The aquatinted knowledge is structured in an adequate knowledge-based system, which is situated in a database, where all decisions and accumulated knowledge is stored. 


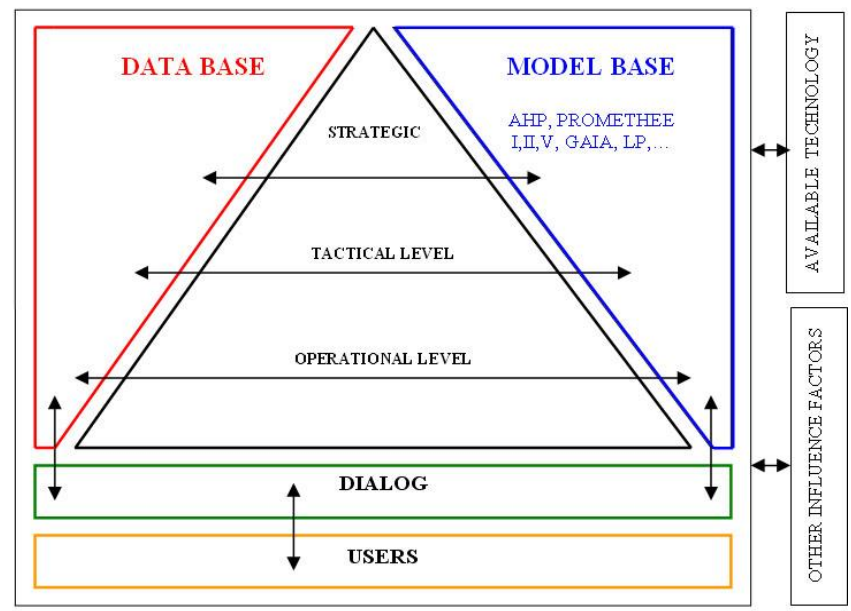

Figure 1 Architecture of the DSS for urban infrastructure management $[3,4,10,16]$

Many outside factors can influence urban infrastructure and its management. In the present work, we will focus on city parking, as it is part of urban road infrastructure. Decision-making and management are affected not only by technology, which influences them at all levels, but also by local behavior, which includes the actual and traditional styles of management and decision-making, the local mentality, and the various groups of stakeholders [3]. Through the present work, we will demonstrate that our proposed DSS provides adequate support for managing city parking projects because they are subsets of urban infrastructure projects. Because we focus only on city parking, we use the logic of the cited DSSs to design a new DSC that is suitable only for managing city parking facilities.

A major inspiration for our work, as stated before, is Jajac et al. [4], who provided a decision support system for managing the maintenance of urban infrastructure. They aimed to provide a DSS that balanced maintenance investments among different parts of the urban road infrastructure in order to balance the quality of the services provided to the users. In contrast, our research focuses on designing a DSC that provides decision-making support related only to managing the maintenance of one type of urban road infrastructure: city parking. We adapted the DSC to the specifics of managing the maintenance of CPFs, considering both the economic/commercial aspects and the technical aspects of CPFs while accounting for environmental issues, and designed it for people making decisions solely in parking management.

\section{DESIGNING AND USING THE DSC TO MANAGE CPF MAINTENANCE}

Using the work cited before, we developed a DSC to support management decisions related to maintaining CPFs. Implementing this DSC depends on the needs of various shareholders and limited resources, most often limited funding in the city budget. These realities show that, generally, decision-making problems related to maintaining CPFs involve priority-setting. The DSC we propose recognizes some of these crucial problems and provides models to support decision-making. Figure 2 proposes an approach to set priorities for maintenance and to establish a maintenance plan by using the DSC.

The decision-making process starts at both the strategic and tactical levels. Here, the spatial boundaries of the research must be selected: all of the city or a section of it. The planning process must be defined as applying to all CPFs or to only the CPFs owned by the city government. It must also be defined as applying only to CPFs managed by the city government, only to CPFs managed by a third party (the concessionaire), or to both. To define the scope of the research, the functional boundaries must also be determined. To support efficient decision-making, the stakeholders must be identified and selected. Stakeholders are divided into three groups: experts in maintaining road infrastructure (particularly parking facilities), local governmental officials connected to managing municipal infrastructure, and representatives of the users. The third group usually consists of elected representatives of districts or similar city formations. 


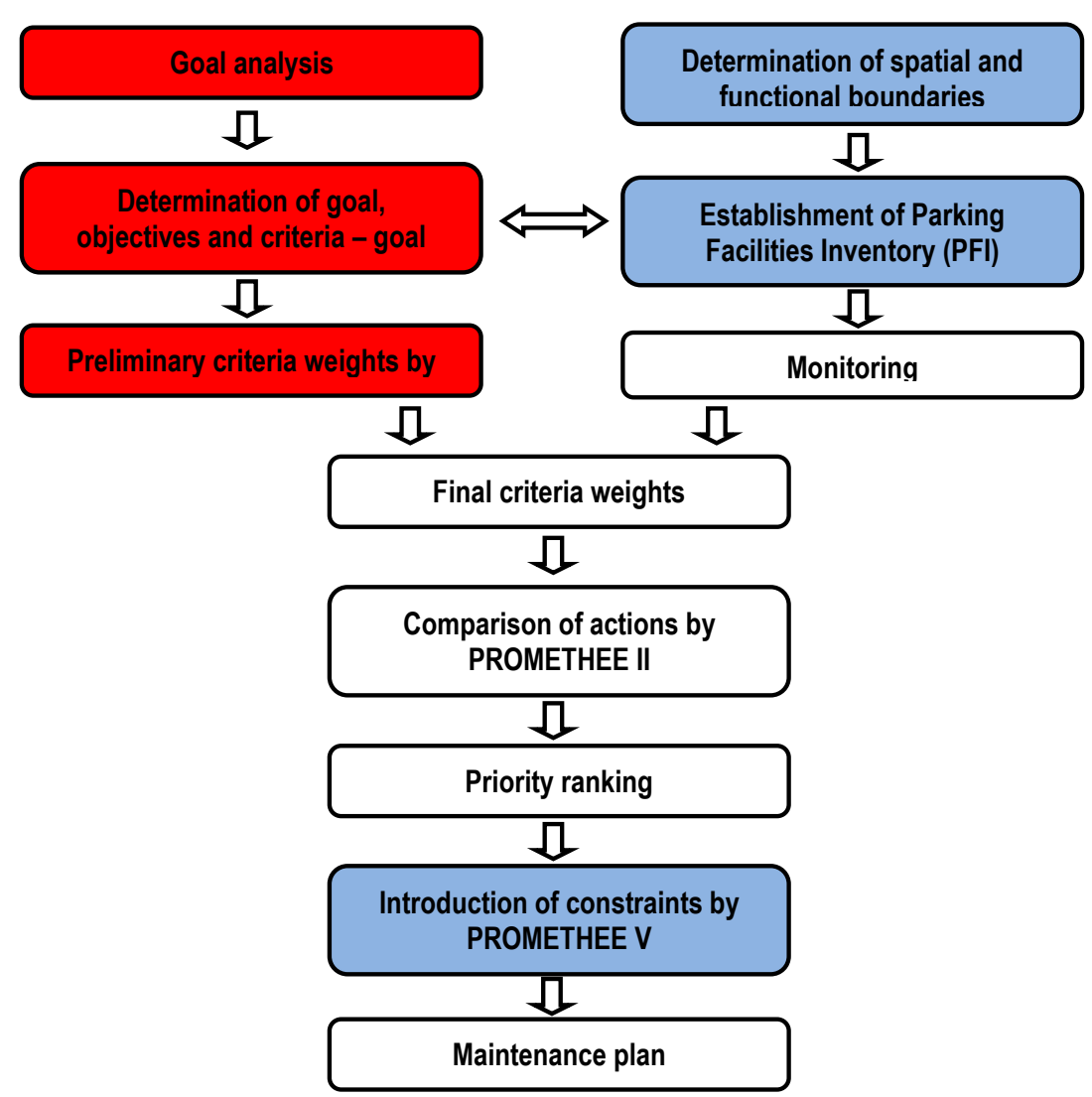

Figure 2 Architecture of DSC used to manage the maintenance of CPFs

After defining the shareholders, on the tactical level a priority-setting model must be set. Because of the illstructured problem that emerges from incomparable data and conflicts in stakeholders' demands, we use a multicriteria model. Multicriteria priority-setting begins with goal analysis and produces a hierarchical goal structure, a goal tree, and the main goal is sustainable maintenance of CPFs.

Next, the objectives of the goal tree must be defined, dividing the main goal into several supporting or firstlevel objectives. Then, sub-objectives of first-level objectives must be provided. The process of generating subobjectives is repeated until the objectives cannot or does not need to be divided further. Objectives and subobjectives must be defined in a way so they can be measured.

After dividing the objectives into sub-objectives, the goal tree is established. The tree provides an overview of the mutual relationships between objectives within the hierarchy, but does not provide any information about the relative importance of objectives at the same level. It is particularly important to determine the relative importance of objectives situated on the same hierarchical level. Because goal analysis is the basis for defining a criterion, criteria are integral to the goal tree. The process of defining the goal tree and its criteria involves the local government officials and experts, while setting up the criteria weights involves opinions from all stakeholder groups.

Using analytic hierarchy processing (AHP) [17], it is easy to assign weights to criteria through group decision-making by interviewing all the stakeholder groups. Multicriteria decision-making is supported by several strategies, also known as scenarios. Each preliminary scenario comprises a different combination of criteria weights, representing the opinion of each stakeholder group. Taking several preliminary scenarios, the compromise scenario (final scenario) can be defined, which will be used for ranking priorities. The final scenario is defined as a set of compromise criteria weights, each of which is the average of the preliminary weights for the criterion over all preliminary scenarios.

In parallel with goal analysis, the DSC identifies the parking facilities in the study area and sets up a parking facilities inventory (PFI). The PFI must contain names and locations of the CPFs and data relevant to managing their maintenance. The relevant characteristics must be known for each CPF because these data will be used as 
criteria for comparing the different CPFs during priority ranking. To assess these characteristics, the CPFs should be comprehensively monitored.

The monitoring program must include forms, a schedule, and a CPF inspection process. The form for assessing the maintenance status must represent a summary of all aspects relevant to managing its maintenance. The most common aspects are as follows: status of signs and signals, status of equipment, status of cross-section, and status of structure. Equally important but usually neglected are data on the costeffectiveness and managerial aspects. Inspecting a CPF combines a visual inspection and other measurements. From the CPF inspection, the condition of the CPF can be determined. Each CPF can be inspected and reassessed in a repeating period from six months to one year, depending on how intensely it is used.

In our research, we ranked priorities by using the PROMETHEE II method [18]. In this method, each CPF represents one action of the multicriteria model. To begin the multicriteria priority-setting process, data from monitoring and inspection are inputted into a decision matrix, generating a ranking of CPFs. Then, a maintenance plan is established. The strategic plans and opinions of the decision-makers (local government) must also be introduced, which can be done in PROMETHEE V, a combination of the PROMETHEE II method and (0-1) linear programming.

The result of PROMETHEE $V$ is a subset of the analyzed CPF, and it can be used to plan and perform maintenance in the first investment cycle. All other phases of maintenance implementation can be determined in the same way. This process generates the maintenance plan. We validated our process in the city of Split.

\section{VALIDATING THE PROPOSED DSC}

Worldwide, urban expansion and the huge growth in vehicle ownership complicates the maintenance of CPFs, especially in densely populated town centers. The town of Split is no exception. The study area we used to validate our DSC is the wider city center of Split, using only CPFs owned and managed by the city government. Table 1 surveys the area and identifies the CPFs and PFI. During monitoring, the conditions of these CPFs were assessed. Monitoring included inspection of on-street parking, off-street parking, and parking garages; that is, all the parking facilities identified within the research area.

Table 1 CPFs in the study area included in the PFI

\begin{tabular}{|c|c|c|c|c|c|}
\hline Code & CPF name & Code & CPF name & Code & CPF name \\
\hline 1 & Zrinsko-Frankopanska-grad & 22 & SPL Mornar & 43 & Zoraniceva \\
\hline 2 & $\operatorname{Trg} \mathrm{HBZ}$ & 23 & SPL Spinut & 44 & $\begin{array}{l}\text { Tolstojeva (Marunova- } \\
\text { Zagrebacka) }\end{array}$ \\
\hline 3 & Sukoisanska & 24 & Konzum-Lora & 45 & Tolstojeva-Public library \\
\hline 4 & Usjek pruge-HEP & 25 & Museum of CAM & 46 & $\begin{array}{l}\text { Trumbiceva obala-Marjanske } \\
\text { skale }\end{array}$ \\
\hline 5 & Lavcevic & 26 & Meje-Zvoncac & 47 & Trumbiceva obala-HGK \\
\hline 6 & Lavcevic-garage & 27 & Sustipan & 48 & Bana Jelacica-HB \\
\hline 7 & Domovinskog rata (east-west) & 28 & Sv. Frane & 49 & Port authority-Riva \\
\hline 8 & Luka & 29 & Matejuška & 50 & Katalinicev prilaz \\
\hline 9 & Goricka & 30 & Lazarica-Firule & 51 & Preradovicevo setaliste-HP \\
\hline 10 & Mazuranicevo setaliste-FINA & 31 & Firule hospital & 52 & Bijankinijeva \\
\hline 11 & Mazuranicevo setaliste-garage & 32 & SC Gripe & 53 & Zagrebacka \\
\hline 12 & Vukovarska & 33 & Sukoisan north & 54 & Svaciceva \\
\hline 13 & Koteks & 34 & Kragiceva-Plinarska & 55 & Svaciceva-Grad \\
\hline 14 & Gripe-Koteks-garage & 35 & Sukoisan-bus terminal & 56 & Gunduliceva \\
\hline 15 & Boskoviceva I & 36 & $\begin{array}{l}\text { Sukoisan - in front of public } \\
\text { garage }\end{array}$ & 57 & Gunduliceva-Dalma \\
\hline 16 & Boskoviceva II & 37 & $\begin{array}{l}\text { Domovinskog rata (bust terminal- } \\
\text { HRM) }\end{array}$ & 58 & Mikaciceva \\
\hline 17 & Poljicka-Brodomerkur & 38 & Train terminal & 59 & Riva-Sv.Frane \\
\hline 18 & Poljicka-Monter & 39 & Pojisan & 60 & Gunduliceva-parking \\
\hline 19 & Krizine hospitall & 40 & Bacvice & 61 & Goricka-parking \\
\hline 20 & Poljud-swimming pools & 41 & Firule-Sumica & 62 & $\begin{array}{l}\text { Poljicka cetsa (Osjecka- } \\
\text { Dubrovacka) }\end{array}$ \\
\hline 21 & Hajduk- football stadium & 42 & Starceviceva & 63 & Vinkovacka-Sucidar market \\
\hline
\end{tabular}


For each CPF, monitoring began with an inspection. The inspector entered data into many forms, and then arranged it into a final monitoring form, shown in Table 2, which was used to estimate the maintenance requirements. The monitoring process should be repeated once a year.

Table 2 Final form for monitoring the maintenance conditions of CPFs

\begin{tabular}{|l|l|l|}
\hline CPF maintenance conditions status assessment & Assessment \\
\hline Signs and signals & Vertical signs, horizontal signs, traffic signals & \\
\hline Equipment & Pavement edge marking equipment, fences, lightening & \\
\hline Cross section elements & $\begin{array}{l}\text { Pavement, gutter and drain, marginal strip, pedestrian path, traffic flow } \\
\text { canalization elements, shoulder, pipe man hole }\end{array}$ & \\
\hline $\begin{array}{l}\text { Characteristics of CPF } \\
\text { structure and other } \\
\text { related characteristics }\end{array}$ & $\begin{array}{l}\text { Fracture, other damages, concrete armature cover, displacement of main } \\
\text { structure elements, bearing, installation, fire protection equipment, } \\
\text { structural elements appearance }\end{array}$ & \\
\hline Capacity & Number of vehicles that can be parked in CPF & \\
\hline Parking fee & Per hour & \\
\hline Occupancy rate & Per year & \\
\hline Billing & Existence of automated or manual billing & \\
\hline Investment & Required financial founds & \\
\hline
\end{tabular}

Figure 3 and Table 3 describe established goal hierarchy for the analyzed problem. Our main goal was "Sustainable maintenance of CPFs in the city of Split," and achieving this goal depends on a stepwise approach to maintaining the $63 \mathrm{CPFs}$. All stakeholders were involved in defining the goals in the lower levels (first and second); from this, the objective tree was configured, as shown in Figure 3.

The main goal and objectives of the first level were defined according to the "Split Development Strategy." This strategy was provided for a time period up to 2015 by the city government and experts, and it was adopted by the city council, the representative body of the city's citizens. The objectives of the second level (later used as criteria) were generated by all members from all three stakeholder groups. After brainstorming, each group provided their objectives. The representatives from all three groups agreed unanimously on which generated objectives would be incorporated in the goal tree. The user group provided the $\mathrm{C} 5$ and $\mathrm{C} 6$ criteria, the expert group provided $\mathrm{C} 1, \mathrm{C} 2, \mathrm{C} 3$, and $\mathrm{C} 4$, and the local government group provided $\mathrm{C} 7, \mathrm{C} 8$, and $\mathrm{C} 9$. Figure 3 , Table 2, and Table 3 show these criteria. Because the criteria for multicriteria analysis form the objective tree, the last hierarchic level of this particular tree represents the criteria set used to rank the CPFs for maintenance priority.

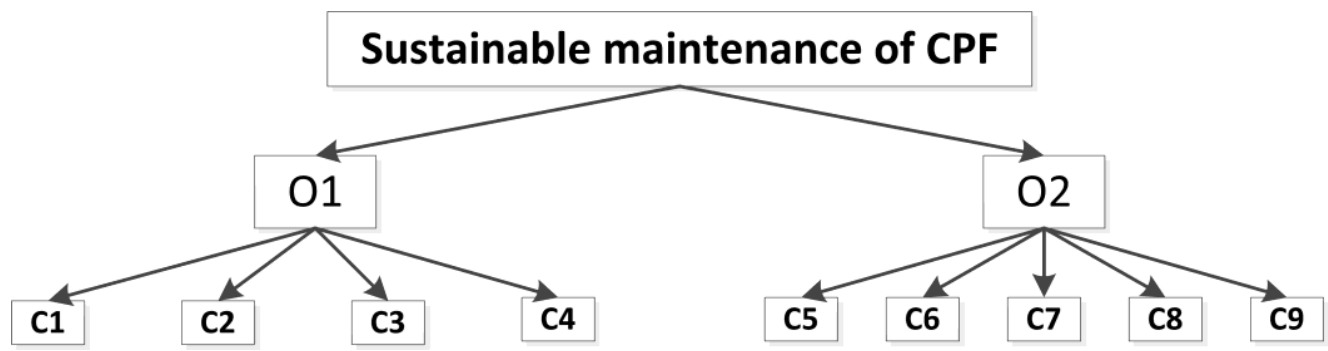

Figure 3 Goal tree (with compromise weights) of the maintenance priority-setting problem for CPFs in the town of Split 
Table 3 Hierarchy, code, and description of the goal, objectives, and criteria

\begin{tabular}{|c|c|c|c|}
\hline Hierarchy level & Criteria label & & Description of goal, objectives, criteria \\
\hline 0 & G & $\overline{\mathrm{O}}$ & Sustainable maintenance of CPF in the city of Split \\
\hline 1 & 01 & \multirow{2}{*}{ 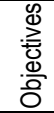 } & Maximization of maintenance quality of CPF (for owners and users) \\
\hline 1 & 02 & & Maximization of cost-effective/managerial sustainability \\
\hline 2 & C1 & \multirow{9}{*}{ 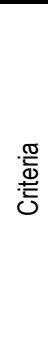 } & Maintenance improvements of traffic signs and signals \\
\hline 2 & $\mathrm{C2}$ & & Maintenance improvements of CPF equipment \\
\hline 2 & $\mathrm{C3}$ & & Maintenance improvements of cross-section elements \\
\hline 2 & C4 & & Maintenance improvements of CFP structure and other characteristics \\
\hline 2 & $\mathrm{C5}$ & & Maximization of CPF capacity \\
\hline 2 & C6 & & Minimization of parking fee \\
\hline 2 & $\mathbf{C 7}$ & & Maximization of occupancy rate \\
\hline 2 & $\mathrm{C8}$ & & Maximization of billing efficiency \\
\hline 2 & C9 & & Minimization of investment founds \\
\hline
\end{tabular}

The criteria weights used to compare actions (by using the PROMETHEE II method) were provided by the AHP method, and all stakeholders were involved in this process. Using the established goal hierarchy (goal tree) and the opinions of the stakeholders groups, three preliminary scenarios were developed. Table 4 shows the three preliminary scenarios with three sets of criteria weights.

he first scenario describes the preferences of the citizens (users), the second describes those of the experts, and the third describes those of the city authorities (local government). The user group comprises 23 elected representatives, one from each district. The expert group comprises 3 experts in maintaining road infrastructure, particularly parking facilities: two scientists from two Croatian universities, and the manager of the company that maintains the roads in Split. The local government group comprises 3 representatives: the deputy mayor, the head of the department of municipal infrastructure management, and one employee of this department who is engaged in maintaining the road infrastructure of Split.

The criteria weights of the three preliminary scenarios were used to calculate the final (fourth) scenario by a simple arithmetic mean, giving equal importance to all stakeholder groups. This fourth scenario is the compromise view, used to execute the DSC.

Table 4 Criteria weights and scenarios

\begin{tabular}{|c|l|c|c|c|c|c|c|}
\hline $\begin{array}{c}\text { Criteria } \\
\text { label }\end{array}$ & \multicolumn{1}{|c|}{ Criteria } & $\begin{array}{c}\text { Scen. } \\
1\end{array}$ & $\begin{array}{c}\text { Scen. } \\
2\end{array}$ & $\begin{array}{c}\text { Scen. } \\
3\end{array}$ & $\begin{array}{c}\text { Average } \\
\text { weight }\end{array}$ & $\begin{array}{c}\text { Preference function } \\
\text { Shape-MIN/MAX }\end{array}$ \\
\hline C1 & $\begin{array}{l}\text { Maintenance improvements of traffic } \\
\text { signs and signals }\end{array}$ & 0.04 & 0.12 & 0.08 & 0.08 & V-Shape & MAX \\
\hline C2 & $\begin{array}{l}\text { Maintenance improvements of CPF } \\
\text { equipment }\end{array}$ & 0.04 & 0.11 & 0.08 & 0.08 & V-Shape & MAX \\
\hline C3 & $\begin{array}{l}\text { Maintenance improvements of cross- } \\
\text { section elements }\end{array}$ & 0.11 & 0.24 & 0.14 & 0.16 & V-Shape & MAX \\
\hline C4 & $\begin{array}{l}\text { Maintenance improvements of CFP } \\
\text { structure and other characteristics }\end{array}$ & 0.11 & 0.22 & 0.14 & 0.16 & V-Shape & MAX \\
\hline C5 & Maximization of CPF capacity & 0.24 & 0.09 & 0.20 & 0.18 & V-Shape & MAX \\
\hline C6 & Minimisation of parking fee & 0.24 & 0.06 & 0.04 & 0.11 & V-Shape & MIN \\
\hline C7 & Maximization of occupancy rate & 0.07 & 0.07 & 0.05 & 0.06 & V-Shape & MAX \\
\hline C8 & Maximization of billing efficiency & 0.07 & 0.03 & 0.07 & 0.06 & Usual & MAX \\
\hline C9 & Minimisation of investment & 0.08 & 0.06 & 0.20 & 0.11 & V-Shape & MIN \\
\hline
\end{tabular}

After creating the final scenario, the multicriteria model for ranking the CPFs was created. It has 9 criteria and 63 actions/alternatives. Table 4 also shows the function used to form each criterion, giving the type of preference function in the seventh column, and whether the variable was to be minimized or maximized in the eighth column. For 8 criteria, the most used type of function is the V-Shape function, while for a single criterion 
Decision support concept for managing the maintenance of city parking facilities

the most used type is the usual function. Table 5 shows the top $10 \mathrm{CPFs}$, ranked based on the weights from the compromise scenario, according to how necessary it is to maintain each.

Table 5 Preference flows and PROMETHEE II ranking for the compromise scenario

\begin{tabular}{|c|c|c|l|}
\hline Ranking & $\boldsymbol{\Phi}$ & Code & \multicolumn{1}{|c|}{ CPF-alternatives/actions } \\
\hline 1 & 0.3210 & 4 & Usjek pruge-HEP \\
\hline 2 & 0.2111 & 49 & Port authority-Riva \\
\hline 3 & 0.2109 & 5 & Lavcevic \\
\hline 4 & 0.1877 & 38 & Train terminal \\
\hline 5 & 0.1593 & 8 & Luka \\
\hline \multirow{2}{*}{6} & 0.1523 & 33 & Sukoisan north \\
\cline { 2 - 4 } & 0.1523 & 34 & Kragiceva-Plinarska \\
\hline 7 & 0.0991 & 7 & Domovinskog rata (east-west) \\
\hline 8 & 0.0701 & 42 & Starceviceva \\
\hline 9 & 0.0612 & 26 & Meje-Zvoncac \\
\hline 10 & 0.0453 & 2 & Trg HBZ \\
\hline
\end{tabular}

However, a few top-ranked alternatives were not selected for the first implementation of the maintenance plan. This was caused by a number of influences, including the opinions of the decision-makers (representatives of city government), which were not covered by any criteria, as well as the availability of required resources, especially financial resources, and the needs for CPFs in particular sections of the study area. To account for these additional influences, several constraints must be introduced.

These constraints were defined with input from the experts and city government representatives. These constraints are defined as a set of linear equations, inequalities, or both. Only one constraint within this set is related to the available financial resources for the next investment cycle $(750,000 \mathrm{EUR})$. All other constraints are related to functional and spatial aspects of the problem, and they are defined as follows: First, at least two CPFs are needed in the contact area of Diocletian Palace; second, at least one CPF is needed in the city port area; third, no more than two CPFs are needed in the area of the civil court house; and fourth, no more than two CPFs are needed in the area of the Marjan city park/forest. By introducing constraints using the PROMETHEE V method, the first phase of the maintenance plan can be finalized, as shown in Table 6 .

Table 6 First phase of the maintenance plan

\begin{tabular}{|c|l|}
\hline Code & CPF-alternatives/actions \\
\hline 4 & Usjek pruge-HEP \\
\hline 49 & Port authority-Riva \\
\hline 26 & Meje-Zvoncac \\
\hline 33 & Sukoisan north \\
\hline 34 & Kragiceva-Plinarska \\
\hline 3 & Sukoišanska \\
\hline 12 & Vukovarska \\
\hline 63 & $\begin{array}{l}\text { Vikovacka-Sucidar } \\
\text { market }\end{array}$ \\
\hline
\end{tabular}

The PROMETHEE $V$ results placed 8 of the 63 CPFs in the first maintenance phase for the next investment cycle. Note that only 5 of these 8 CPFs were ranked in the top 10 ranked CPFs, as shown in Table 5. 


\section{CONCLUSION}

Supporting complex and sensitive decision-making processes such as ranking priorities for maintenance of CPFs cannot be achieved without using DSS principles and appropriate multicriteria methods, along with the data they require. To consider such an approach, we studied previous DSSs for infrastructure management, concepts for supporting the management of maintaining urban road infrastructure elements, and project lifecycle methodologies. Our new DSC, used to manage the maintenance of CPFs, is a combination of operational models and multicriteria models.

Our DSC functioned well when applied to CPFs owned and managed by the city government of Split, and it can be used for all other types of road infrastructure. Maintenance decision-making processes can be supported at all hierarchy levels by interactions among the DSC modules. By creating a monitoring program, the data needed to define the maintenance status of the CPFs could be acquired in uniform amounts and on a uniform schedule.

The multicriteria analysis has several methodological and sociopolitical advantages when resolving complex problems such as planning the maintenance of CPFs, regardless of decision level. The stakeholders were divided into three different groups (citizens, maintenance experts, and representatives of city authorities), and they were all directly involved in the decision-making. They were involved in designing the goal hierarchy (generating objectives, sub-objectives, and criteria), by which they shaped the criteria of the alternative CPF assessment. Their opinions are expressed by criteria weights, clarifying the planning and implementation of maintenance while removing mistrust and biased situations.

The obtained solution, expressed as a CPF subset, provided by PROMETHEE $V$ according to defined maintenance criteria and introduced constraints, is a possible strategic alternative in managing the maintenance of the CPFs. It represents the first phase or first step of the CPF maintenance plan, ensuring stepwise achievement of the main goal, "Sustainable maintenance of CPF in the city of Split."

\section{References}

[1] Bielli, M. 1992: A DSS approach to urban traffic management, European Journal of Operational Research, Volume 61, Issues 1-2, pp. 106-113.

[2] Guisseppi, A.; Forgionne, G. A. 2002: Selecting rail grade crossing investments with a decision support system, Information Sciences, Volume 144, Issues 1-4, pp. 75-90.

[3] Jajac, N.; Knezić, S.; Mladineo, N. 2008: DSS for urban infrastructure management, Parking garages case study, Book of proceedings, 8th International Conference on Organization, Technology and Management in Construction, Umag, Croatia.

[4] Jajac, N.; Knezić, S.; Marović, I. 2009: Decision support system to urban infrastructure maintenance management, Organization, Technology \& Management in Construction, Volume 1, Issue 2, pp. 72-79.

[5] Quintero, A.; Konaré, D.; Pierre, S. 2005: Prototyping an intelligent decision support system for improving urban infrastructures management, European Journal of Operational Research, Volume 162, Issue 3, pp. 654-672.

[6] Leclerc, G.; Hmiya, S.; Aïmeur, E.; Quintero, A.; Pierre, S.; Ochoa, G. 2001: An intelligent decision support system (IDSS) for an urban infrastructure complaint management module. World Multiconference on Systemics, Cybernetics and Informatics, ISAS/SCI 2001, Orlando, Florida, Volume XVIII, 143-147.

[7] Coutinho-Rodrigues, J.; Simao, A.; Antunes, C. H. 2011: A GIS-based multicriteria spatial decision support system for planning urban infrastructures, Decision Support System, Volume 51, Issue 3, pp. 720-726.

[8] Burstein, F. 1995: IDSS: Incorporating knowledge into decision support systems, Burstein, F.; O'Donnell, P. A.; Gilbert, A. (Eds.), Proceedings of the Workshop on Intelligent Decision Support-IDS'95, Monash University, Melbourne, pp. 93-96.

[9] Jajac, N.; Knezić, S.; Babić, Z. 2010: Integration of multicriteria analysis into decision support concept for urban road infastructure management, Croatian Operational Research Review, Volume 2, Issue 1, pp. 74 83.

[10] Jajac, N.; Marović, I. 2014: Management of urban road infrastructure projects - decision support concept to maintenance planning, International Review of Civil Engineering, Volume 5, Issue 5, pp. 156-162. 
[11] Turban, E.; Aronson J. E. 1995: Decision support systems and intelligent systems, (5th ed.), Simon and Schuster Company, Upper Saddle River, NJ.

[12] Pomerol, J.; Roy, B.; Rosenthal-Sabroux, C. 1996: Development of an "intelligent" system for the evaluation of railway timetables: Problems and issues, Journal of Decision Systems, Volume 5, pp. 249-267.

[13] Rouse, P.; Chiu, T. 2009: Towards optimal life cycle management in a road maintenance setting using DEA, European Journal of Operational Research, Volume 196, Issue 2, pp. 672-681.

[14] Huang, Y.; Bird, R.; Heidrich, O. 2009: Development of a life cycle assessment tool for construction and maintenance of asphalt pavements, Journal of Cleaner Production, Volume 17, Issue 2, pp. 283-296.

[15] Huang, Y.; Bird, R.; Bell, M. 2009: A comparative study of the emissions by road maintenance works and the disrupted traffic using life cycle assessment and micro-simulation, Transportation Research Part D: Transport and Environment, Volume 14, Issue 3, pp. 197-204.

[16] Jajac, N. 2007: Decision support system for urban infrastructure management, MSc thesis, University of Split, Faculty of Economics, Split.

[17] Saaty, T. L. 2001: Decision Making for Leaders, The Analytic Hierarchy Process SFOR Decisions in a Complex World, Third Edition, University of Pittsburgh, 322 Mervis Hall, Pittsburgh.

[18] Brans, J.-P.; Vincke, Ph. 1984: Preference Ranking Organisation Method for Enrichment Evaluations (The PROMETHEE Method for Multiple Criteria decision Making), Centrum voor Statistiek en Operationeel Onderzoek, Vrije Universiteit, Brussel. 